\title{
Effects of milk replacer program fed 2 or 4 times daily on nutrient intake and calf growth ${ }^{1}$
}

\author{
A. D. Kmicikewycz, D. N. L. da Silva, J. G. Linn, and N. B. Litherland ${ }^{2}$ \\ Department of Animal Science, University of Minnesota, St. Paul 55108-6118
}

\begin{abstract}
The aims of this study were to determine if feeding frequency $(\mathrm{FF})$ of milk replacer (MR; meals/d) alters starter intake, growth, and efficiency of growth in nursery calves fed a conventional or accelerated MR. We hypothesized that smaller and more frequent MR meals would increase starter intake and growth when greater amounts of MR nutrients are fed to nursery calves. Forty-eight Holstein and Holstein-cross heifer and bull calves were assigned to treatments in a $2 \times 2$ factorial arrangement of MR and FF. Treatments included (1) standard $20 \% \mathrm{CP}$ and $20 \%$ fat MR fed at $1.5 \%$ of body weight (BW; 2 meals/d; STD2), (2) standard 20\% CP and $20 \%$ fat MR fed at $1.5 \%$ of BW (4 meals/d; STD4), (3) modified $26 \% \mathrm{CP}$ and $18 \%$ fat MR fed at $2.0 \%$ of BW (2 meals/d; MOD2), and (4) modified 26\% CP and $18 \%$ fat MR fed at 2.0\% of BW (4 meals/d; MOD4; $\mathrm{n}=12$ ). All calves were fed at 0600 and $1700 \mathrm{~h}$ and STD4 and MOD4 calves were fed 2 additional meals at 1100 and $1400 \mathrm{~h}$, resulting in the same amount of MR offered for the $2 \times$ and $4 \times$ treatments. Treatments were fed from d 2 to 42 of age and all MR feeding rates were adjusted weekly to maintain MR solids intakes at 1.5 or $2.0 \%$ of BW for STD and MOD diets, respectively, and were reconstituted to $15 \%$ total solids. Milk replacer FF was reduced by $50 \%$ on d 36 and calves were weaned on d 42. Calves were housed in hutches bedded with straw and offered water and a texturized $18 \% \mathrm{CP}$ starter ad libitum. Calf body weight and body structure were measured weekly and starter intake and fecal scores were measured daily. Through both 42 and $56 \mathrm{~d}$, calves fed MOD had greater CP and fat intake, resulting in increased average daily gain, heart girth, circulating nonesterified fatty acids (NEFA), and muscle total lipid compared with calves fed STD diets. Calves fed MOD diets consumed less starter grain than STD calves but total dry matter intake was similar among treatments.
\end{abstract}

\footnotetext{
Received May 15, 2012.

Accepted October 9, 2012.

${ }^{1}$ Supported in part by funds from State of Minnesota and USDACSREES appropriated to the Minnesota Agricultural Experiment Station.

${ }^{2}$ Corresponding author: lithe003@umn.edu
}

Increased FF for STD calves resulted in greater starter intake at weaning but increasing $\mathrm{FF}$ of MOD calves did not have this effect. Due to differences in starter intake, total dry matter by calves through d 56 was similar across treatments. Additionally, increased FF tended to increase serum NEFA concentrations. Serum NEFA concentration was negatively correlated with starter intake. The BW of calves fed STD2 and STD4 treatments almost doubled and the BW of calves on the MOD2 and MOD4 treatments doubled by $\mathrm{d} 56$. Increased $\mathrm{FF}$ of the conventional $\mathrm{MR}$ program but not accelerated MR program increased starter intake. Increased FF did not affect growth, starter intake, or gain:feed ratio.

Key words: nursery calf, accelerated milk replacer, feeding frequency

\section{INTRODUCTION}

Current industry practice is to provide calves with whole milk or milk replacer (MR) at approximately $10 \%$ of the calf's BW divided into 2 meals per day (Jasper and Weary, 2002). Conventional calf-rearing systems historically have restricted the amount and frequency of feeding (FF) of MR to about $0.25 \mathrm{~kg}$ in $2 \mathrm{~L}$ of water fed twice per day. Under this feeding program, a 40-kg calf would receive 2 meals per day of approximately $2 \mathrm{~kg}$ as fed. In contrast, a calf left with its dam will suckle, on average, 7 to 10 times per day and consume substantially larger quantities of milk (Albright and Arave, 1997). Additionally, the cow and calf interaction plays a major role in controlling the duration and frequency of each suckling event and, thus, total MR intake (von Keyserlingk and Weary, 2007). Furthermore, in cold climates, increasing the number of feedings from 2 to 3 times/d and increasing the amount of DM fed has improved weight gain and calf health (Schingoethe et al., 1986). The objective of earlier calf-rearing systems was to encourage starter intake (SI), promote development of a functional rumen, and reduce the age at weaning (Kertz et al., 1979). Increasing the intake of nutrients from MR generally delays or reduces starter and forage intake (Jasper and Weary, 2002; Terré et al., 2009; Davis Rincker et al., 
2011; Morrison et al., 2012). An inverse relationship between milk or MR and SI has been demonstrated in earlier research (Raeth-Knight et al., 2009; Terré et al., 2009). However, over the past several years, research has shown that improvements in growth and feed efficiency can be obtained by feeding greater quantities of MR or increased concentration of nutrients in MR (Diaz et al., 2001; Flower and Weary, 2001; Jasper and Weary, 2002; Brown et al., 2005).

In addition to nutrient intake and quantities of milk or MR offered, FF also can be manipulated to alter nutrient intake and modify the amount of delivery of nutrients throughout the day. Increased FF or feed push-up increased DMI in lactating cows (Bach et al., 2008). There is a paucity of data describing the effects of increasing MR FF on calf growth and health.

We hypothesized that increased FF would result in increased SI and calf growth when calves were fed an accelerated MR program. The objectives of this study were to determine if the MR program: standard (20\% $\mathrm{CP}$ and $20 \%$ fat fed, at $1.5 \%$ of $\mathrm{BW}$ ) versus modified accelerated $(26 \% \mathrm{CP}$ and $18 \%$ fat fed, at $2.0 \% \mathrm{BW})$ and FF (2 vs. 4 times daily) would alter calf SI, growth, and health of manually fed calves.

\section{MATERIALS AND METHODS}

\section{Animals}

The experimental protocol was reviewed and approved by the University of Minnesota (St. Paul) Institutional Animal Care and Use Committee. Forty-eight $(\mathrm{n}=12)$ Holstein and Holstein-cross female $(\mathrm{n}=24)$ and male $(\mathrm{n}=24)$ calves averaging $41.8 \pm 1.6 \mathrm{~kg}$ of $\mathrm{BW}$ at birth were used. Calves were born between October 21, 2009, and February 1, 2010, at the University of Minnesota Dairy Research and Teaching Facility (St. Paul).

At birth, calves were removed from their dams and weighed. Each calf was identified with a unique ear tag and placed in a calf hutch (Calf-Tel; Hampel Corp., Germantown, WI and PolyDome, Litchfield, MN) bedded with straw within $24 \mathrm{~h}$ of birth. Calves received approximately $1.9 \mathrm{~L}$ of colostrum at each of the first 2 feedings (within $2 \mathrm{~h}$ after birth and again approximately $12 \mathrm{~h}$ after the first feeding) and were trained to drink MR from buckets during the first $2 \mathrm{~d}$ of life. A blood sample was collected via jugular venipuncture into evacuated serum collection tubes (SST; Vacutainer; Becton, Dickinson and Co., Franklin Lakes, NJ) $24 \mathrm{~h}$ after birth and centrifuged at 2,000 $\times g$ for 20 min. Serum was separated and analyzed for total serum protein concentration using a refractometer (Reichert Rhino VET360; Reichert Inc., Depew, NY).

\section{Assignments to Treatments and Feeding}

Calves were balanced by birth BW, sex, breed, and serum total protein content across the 4 treatment combinations. The MR treatments were as follows: control (STD2; standard 20\% CP and 20\% fat MR fed at $1.5 \%$ of birth BW in 2 meals/d); standard $20 \%$ CP and $20 \%$ fat MR fed at $1.5 \%$ of birth BW in 4 meals/d (STD4); modified $26 \% \mathrm{CP}$ and $18 \%$ fat MR fed at $2.0 \%$ of birth BW in 2 meals/d (MOD2); and modified $26 \% \mathrm{CP}$ and $18 \%$ fat MR fed at $2.0 \%$ of birth BW in 4 meals/d (MOD4). Milk replacer feeding rates of STD were increased above the typical daily 0.40 to $0.55 \mathrm{~kg}$ of DM per calf to minimize the risk of adverse health events during cold stress typical during winter in the upper Midwest.

Of the 48 calves assigned to treatment, 3 calves were replaced during the trial. Two calves assigned to STD2 were replaced; 1 calf was replaced at d 35 of age due to extremely poor performance and an abscess on its lower jaw and the second calf was replaced at d 14 of age after it died. A third calf on STD4 was replaced at d 28 of age due to a leg injury.

All MR were manufactured by Milk Products Inc. (Chilton, WI), were medicated (220 g of oxytetracycline and $485 \mathrm{~g}$ of neomycin base per metric tonne; fed before the 2009 Food and Drug Administration ruling on medicating MR), and contained whey protein as the protein source and edible-grade lard as the fat source. All MR was reconstituted to $15 \%$ solids and offered to calves in buckets. Treatments were fed from d 1 to 42 and all MR feeding rates were adjusted weekly to maintain 1.5 or $2.0 \%$ of BW for STD and MOD treatments, respectively. Calves on treatments STD4 and MOD4 were fed 4 meals/d at 0600, 1100, 1400, and $1700 \mathrm{~h}$ and 2 meals at 0600 and $1700 \mathrm{~h}$ from d 37 to 42 . Calves on treatments STD2 and MOD2 were fed 2 meals/d at 0600 and $1700 \mathrm{~h}$ from d 1 to 36 and 1 meal $/ \mathrm{d}$ at $0600 \mathrm{~h}$ from 36 to 42. Calves on treatments MOD2 and MOD4 were fed at $1.5 \%$ of $\mathrm{BW}$ from d 1 to 10 and MR was adjusted to $2.0 \%$ of BW from d 11 to 42 . At 5 wk of age, the total volume of reconstituted MR offered was reduced by $50 \%$ for all calves.

All calves were fed a common starter grain (SG) to meet or exceed nutrient requirements for a preweaned and early weaned Holstein calf to achieve adequate growth as suggested by the NRC (2001) and others (Davis and Drackley, 1998). Texturized SG (Table 1) was fed once daily in the afternoon for ad libitum intake during the first $56 \mathrm{~d}$ of age. Starter refusals were recorded daily and refusals of MR were recorded at each feeding. Warm fresh water was available to calves for ad libitum consumption after each feeding. 
Table 1. Ingredient and chemical composition ${ }^{1}$ of milk replacers (MR) and starter grain for calves fed either a 20:20 or 26:18 MR 2 or 4 times daily $^{2}$

\begin{tabular}{lccc}
\hline & \multicolumn{2}{c}{ Treatment } & \\
\cline { 2 - 3 } Item & $20: 20 \mathrm{MR}$ & $26: 18 \mathrm{MR}$ & $\begin{array}{c}\text { Starter } \\
\text { grain }\end{array}$ \\
\hline Ingredient, g/kg & & & \\
Protein pellets & - & - & 40.0 \\
Flaked corn & - & - & 38.0 \\
Whole oats & - & - & 15.0 \\
Molasses & - & - & 7.0 \\
Nutrient & 97.2 & 96.8 & 84.8 \\
DM, \% & 20.8 & 27.7 & 23.0 \\
CP, \% of DM & 21.2 & 19.0 & 4.3 \\
Fat, \% of DM & - & - & 7.9 \\
Ash, \% of DM & - & - & 1.25 \\
Ca, \% of DM & - & - & 0.62 \\
P, \% of DM & - & - & 0.32 \\
Mg, \% of DM & - & - & 1.61 \\
K, \% of DM & & - & \\
\hline
\end{tabular}

${ }^{1}$ Determined by Dairyland Laboratories Inc. (Arcadia, WI).

${ }^{2}$ The 20:20 MR contained $20 \% \mathrm{CP}$ and $20 \%$ fat; the 26:18 MR contained $26 \% \mathrm{CP}$ and $18 \%$ fat

${ }^{3}$ Nutrient composition of protein pellets: $33.5 \% \mathrm{CP}, 1.45 \%$ ether extract, $7.95 \% \mathrm{ADF}, 2.06 \% \mathrm{Ca}, 0.8 \% \mathrm{P}, 0.54 \% \mathrm{Na}, 0.77 \% \mathrm{Cl}, 0.44 \% \mathrm{Mg}$ $1.58 \% \mathrm{~K}$, and $0.5 \% \mathrm{~S}$.

Average daytime high and low temperatures in the St. Paul area ranged from -6 and $-14^{\circ} \mathrm{C}$ in January to a high of $19^{\circ} \mathrm{C}$ and a low of $7^{\circ} \mathrm{C}$ in April for the months evaluated (Weather Underground, St. Paul, MN). The mean temperature for the study site from October 2009 to April 2010 was $5 \pm 1.1^{\circ} \mathrm{C}$.

\section{Feed Analysis}

Samples of MR and SG were collected weekly and composited monthly. Samples were stored frozen $\left(-20^{\circ} \mathrm{C}\right)$ before analysis for DM, CP, ether extract, ash, Ca, P, K, and Mg (AOAC, 1990). Analysis was conducted by Dairyland Laboratories Inc. (Arcadia, WI). Starter samples were analyzed in duplicate for moisture content (AOAC, 1990). Crude protein (AOAC International, 2000) was analyzed using a Leco FP-528 nitrogen combustion analyzer (Leco Corp., St. Joseph, $\mathrm{MI})$.

\section{Body Growth and Health Monitoring}

Calves were weighed at birth and each Tuesday at 0800 h. Body length, heart girth (dairy calf weigh tape; Fort Atkinson, Nasco, WI), hip width, and hip height (measuring stick, Fort Atkinson) were also measured. Calculations of ADG of BW and stature were made from these measurements. Calves were observed at least twice daily from 1 to $56 \mathrm{~d}$ of age for general health, including appearance (alertness) and appetite (ability to consume feed). Fecal scores: $1=$ normal, firm, and well formed; $2=$ semi-formed, pasty; $3=$ loose, but stays on top of bedding; and $4=$ watery, readily absorbed into bedding were recorded daily from 1 to $56 \mathrm{~d}$ of age. Scours were defined as fecal score $\geq 3$. Scours were treated with oral electrolytes (Bounce Back; Manna Pro Products LLC, Chesterfield, MO) and continued MR feeding.

\section{Blood Collection and Analyses}

Jugular blood (ca. $6 \mathrm{~mL}$ ) was collected into evacuated tubes containing sodium heparin (Vacutainer; Becton, Dickinson and Co.) on d 14, 21, 35, and 42 before the a.m. feeding. Plasma samples were kept on ice after collection and were transported to the laboratory within $1 \mathrm{~h}$. Immediately after arrival at the laboratory, the samples were centrifuged at $2,000 \times g$ at $4^{\circ} \mathrm{C}$ for 20 min. After centrifugation, plasma was decanted into individually labeled $12 \times 75$-mm polypropylene tubes (Becton, Dickinson and Co.), and stored in a $-20^{\circ} \mathrm{C}$ freezer until analyzed for NEFA concentrations. Using commercial spectrophotometric kits, serum was analyzed in duplicate for NEFA concentrations (NEFA-C Kit, ACS-ACOD method; Wako Chemicals USA Inc., Richmond, VA).

Muscle biopsies were collected from each calf on d 21 and 42. Calves were aseptically biopsied from the left semitendinosus muscle on $\mathrm{d} 21$ and from the right semitendinosus muscle on d 42. A local anesthetic (4 $\mathrm{mL}$ of $2 \%$ lidocaine hydrochloride) was injected both intramuscularly and subcutaneously distal to the tuber ischia and then a 2-cm incision was made using a sterile scalpel blade. Approximately $50 \mathrm{mg}$ of muscle tissue was removed using a biopsy needle. Muscle tissue was snap frozen in liquid nitrogen and stored frozen $\left(-80^{\circ} \mathrm{C}\right)$ until analysis for total lipids (Hara and Radin, 1978).

\section{Experimental Design and Statistical Analysis}

The experimental design was a $2 \times 2$ factorial arrangement of treatments. Statistical analyses were conducted utilizing PROC MIXED of SAS (version 9.2; SAS Institute, 2001). The model contained calf within treatment as a random effect and the effects of $\mathrm{MR}, \mathrm{FF}$, interaction of $\mathrm{MR}$ and $\mathrm{FF}$, breed (Holstein vs. Holstein cross), and sex. Data was run through 3 covariance structures: unstructured, compound symmetry, and first-order autoregressive. First-order autoregressive was found to be the most appropriate for all variables due to smaller Bayesian information criteria values. Birth BW was used as a covariate for BW gain. A significant effect of treatment by week was observed for SI, so each week of SI data was analyzed separately. 
Table 2. Serum total protein, BW, ADG, and ratio of feed to gain for nursery calves from d 1 to 42 and d 1 to 56 fed either a 20:20 or 26:18 milk replacer $(\mathrm{MR}) 2$ or 4 times daily $(\mathrm{n}=12)^{1}$

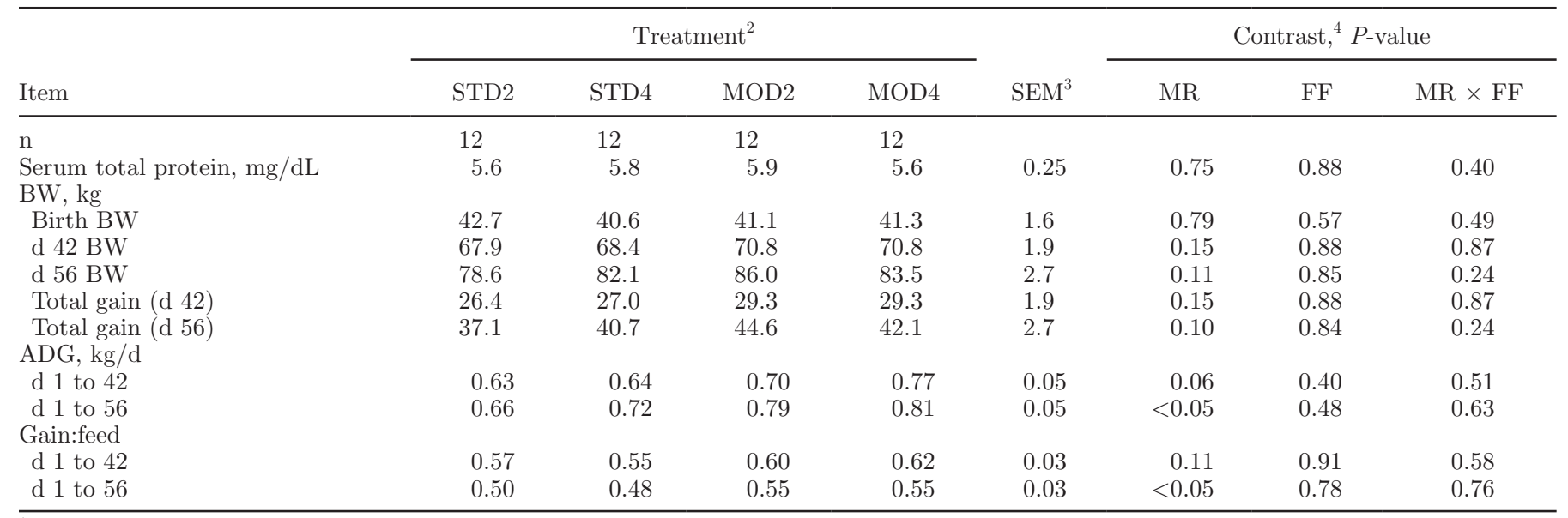

${ }^{1}$ The $20: 20 \mathrm{MR}$ contained $20 \% \mathrm{CP}$ and $20 \%$ fat; the $26: 18 \mathrm{MR}$ contained $26 \% \mathrm{CP}$ and $18 \%$ fat.

${ }^{2}$ STD2 = conventional MR (20\% CP and $20 \%$ fat) fed twice daily at $1.5 \%$ of BW; STD $4=$ conventional MR (20\% CP and $20 \%$ fat) fed 4 times daily at $1.5 \%$ of BW; MOD2 = modified MR $(26 \% \mathrm{CP}$ and $18 \%$ fat $)$ fed twice daily at $2.0 \%$ of BW; MOD $4=$ modified MR $(26 \% \mathrm{CP}$ and $18 \%$ fat) fed 4 times daily at $2.0 \%$ of BW. Calves on all treatments were weaned at $42 \mathrm{~d}$. An $18 \% \mathrm{CP}$ starter and water were offered free choice.

${ }^{3}$ Largest SEM for treatment effects.

${ }^{4} \mathrm{MR}=20: 20 \mathrm{MR}$ versus 26:18 $\mathrm{MR} ; \mathrm{FF}=$ feeding frequency (2 vs. 4 times $\left./ \mathrm{d}\right) ; \mathrm{MR} \times \mathrm{FF}=$ interaction between $\mathrm{MR}$ and $\mathrm{FF}$.

The PDIFF statement of SAS was used for mean separation and significant differences were declared at $P<$ 0.05 , and trends toward significant effects were noted at $P \leq 0.10$. Least squares means and the largest standard error among treatments are reported.

\section{RESULTS AND DISCUSSION}

\section{Diet Composition}

Ingredient and nutrient composition of $\mathrm{MR}$ and $\mathrm{SG}$ are listed in Table 1. Milk replacers were formulated to contain 20 and $26 \% \mathrm{CP}$ respectively, on an as-fed basis and actual analyzed CP content on a DM basis was 20.8 and $27.7 \%$ respectively. The SG was formulated to contain $18 \% \mathrm{CP}$ on an as-fed basis and measured $\mathrm{CP}$ content was $23.0 \%$ on a DM basis.

\section{Calf Growth}

Serum total protein average $(5.7 \pm 0.3 \mathrm{mg} / \mathrm{dL})$ and birth BW average $(41.4 \pm 1.6 \mathrm{~kg})$ were not different among treatments (Table 2). Calf BW on d 42 was unaffected by $\mathrm{MR}(P=0.15)$ or $\mathrm{FF}(P=0.88)$. Additionally, calf BW on d 56 was unaffected by MR $(P$ $=0.11)$ or FF $(P=0.85)$. Body weight gain from d 1 to 42 was not significantly different between MR ( $P$ $=0.15)$ or between $\mathrm{FF}(P=0.88)$ and averaged 26.4 and $27.0 \pm 1.9 \mathrm{~kg}$ for STD2 and STD4, respectively, whereas MOD2 and MOD4 calves gained 29.3 and 29.3 $\pm 1.9 \mathrm{~kg}$, respectively. Body weight gain from d 1 to 56 tended $(P=0.10)$ to be higher for calves fed the accelerated MR program regardless of FF $(P=0.84)$ and averaged $37.1,40.7,44.6$, and $42.1 \pm 2.7 \mathrm{~kg}$ for STD2, STD4, MOD2, and MOD4 calves, respectively. Contrary to results from this study, stimulation of growth by increasing dietary $\mathrm{CP}$ has been reported previously in calves (Donnelly and Hutton, 1976; Gerrits et al., 1996; Diaz et al., 2001; Brown et al., 2005; Bartlett et al., 2006). Brown et al. (2005) reported increased BW $(12.1 \mathrm{~kg})$ and calf height $(2.4 \mathrm{~cm})$ on d 56 for calves fed an intensive (30.3\% CP and $15.9 \%$ fat) as compared with a conventional $(21.3 \% \mathrm{CP}$ and $21.3 \%$ fat) MR feeding program.

Calves fed MOD diets had greater ADG and gain:feed (G:F) ratios, which agrees with previous experiments in which calves were fed greater amounts of milk (Jasper and Weary, 2002; Khan et al., 2007) or MR (Diaz et al., 2001; Blome et al., 2003; Bartlett et al., 2006; Cowles et al., 2006; Hill et al., 2008; Terré et al., 2009; Davis Rincker et al., 2011; Morrison et al., 2012). Calves fed MOD diets tended to have greater $(P=0.06)$ ADG during d 1 to 42 and had higher $(P<0.05)$ ADG d 1 to 56 than calves fed STD diets; however, no effect of FF was observed. Feed efficiency (G:F ratio) at $42 \mathrm{~d}$ of age was similar $(P=0.11)$ among treatments; however, feed efficiency was greater $(P<0.05)$ for calves fed MOD diets at $56 \mathrm{~d}$ of age. Greater feed efficiency for MOD calves is not surprising, given that a higher proportion of their DMI was the more digestible MR compared with SI. Feeding frequency did not alter feed efficiency in this study. 
Table 3. Body growth measurement gains from d 1 to 56 or calves fed a 20:20 MR twice or 4 times daily and calves fed a 26:18 milk replacer $(\mathrm{MR})$ either twice or 4 times daily $(\mathrm{n}=12)^{1}$

\begin{tabular}{|c|c|c|c|c|c|c|c|c|}
\hline \multirow[b]{2}{*}{ Item } & \multicolumn{4}{|c|}{ Treatment $^{2}$} & \multirow[b]{2}{*}{$\mathrm{SEM}^{3}$} & \multicolumn{3}{|c|}{ Contrast, ${ }^{4} P$-value } \\
\hline & STD2 & STD4 & MOD2 & MOD4 & & MR & FF & $\mathrm{MR} \times \mathrm{FF}$ \\
\hline Hip height & 10.8 & 10.5 & 10.1 & 12.4 & 0.50 & 0.39 & 0.19 & 0.09 \\
\hline Hip width & 4.0 & 4.9 & 4.2 & 5.0 & 0.50 & 0.77 & 0.12 & 0.88 \\
\hline Wither height & 8.9 & 10.2 & 10.3 & 11.7 & 0.96 & 0.14 & 0.15 & 0.96 \\
\hline
\end{tabular}

${ }^{1}$ The 20:20 MR contained $20 \% \mathrm{CP}$ and $20 \%$ fat; the $26: 18 \mathrm{MR}$ contained $26 \% \mathrm{CP}$ and $18 \%$ fat.

${ }^{2}$ STD2 $=$ conventional MR $(20 \% \mathrm{CP}$ and $20 \%$ fat $)$ fed twice daily at $1.5 \%$ of BW; STD $4=$ conventional MR (20\% CP and $20 \%$ fat) fed 4 times daily at $1.5 \%$ of BW; MOD2 = modified MR (26\% CP and $18 \%$ fat) fed twice daily at $2.0 \%$ of BW; MOD $4=$ modified MR (26\% CP and $18 \%$ fat) fed 4 times daily at $2.0 \%$ of BW. Calves on all treatments were weaned at $42 \mathrm{~d}$. An $18 \%$ CP starter and water were offered free choice.

${ }^{3}$ Largest SEM for treatment effects.

${ }^{4} \mathrm{MR}=20: 20 \mathrm{MR}$ versus 26:18 MR; FF $=$ feeding frequency ( 2 vs. 4 times $\left./ \mathrm{d}\right) ; \mathrm{MR} \times \mathrm{FF}=$ interaction between $\mathrm{MR}$ and $\mathrm{FF}$.

Milk replacer and FF had no effect on hip height, withers height, or hip width gain (Table 3). An interaction between MR and FF indicated that MOD4 calves tended $(P=0.09)$ to have the greatest hip height gain. Both MOD diets and FF increased $(P<0.05)$ heart girth diameter. Calves fed the MOD4 diet had a larger heart girth than calves on STD2, STD4, and MOD2 diets. In a similar study, Cowles et al. (2006) reported increased ADG during the preweaning period and increased heart girth overall for calves fed an intensive compared with a conventional MR. Calves fed MOD diets tended $(P=0.09)$ to have greater body length gains than STD-fed calves.

\section{MR and SI}

As planned, MR intake was higher $(P<0.05)$ for MOD than STD calves (Table 4). The amount of MR intake within STD and MOD treatments was unaffected by FF. Increased MR intake increased ADG and G:F ratios but reduced SI through weaning, as reported in other studies where a greater amount of milk (Jasper and Weary, 2002; Borderas et al., 2009) or MR (Jenny et al., 1982; Huber et al., 1984; Brown et al., 2005; Cowles et al., 2006; Quigley et al., 2006; Hill et al., 2008) was fed to nursery calves. Milk replacer did not affect SG intake during wk 1 when SG intake was low for all treatments but MOD treatments reduced $(P<$ $0.05)$ SG intake from wk 2 through wk 6 and tended $(P=0.09)$ to reduce $\mathrm{SG}$ intake in wk 7 , with all treatments resulting in similar amounts of SG intake in wk 8. Feeding frequency did not affect $S G$ intake but MR $\times$ FF interactions were observed. Increasing FF from 2 to 4 times/d for STD4-fed calves resulted in a tendency $(P=0.06)$ for higher SG intake in wk 5 and had higher $(P<0.05)$ SG intake in wk 6 than MOD4-fed calves. Evening feedings of MR were discontinued to facilitate weaning after wk 5 . Increased SG intake in wk 5 and 6 for STD but not MOD treatments indicates that increased FF reduced meal size and, thus, nutrient intake from MR enough to stimulate SG intake for STD but not enough to increase SG intake for MOD calves. This effect potentially would have been greater had the amount of MR fed been fixed based on birth $\mathrm{BW}$. Increasing the amount of MR fed to maintain the feeding rate at 1.5 and $2.0 \%$ of BW resulted in greater amounts of MR being fed, as calves gaining weight may have affected the rate and amount of SG intake. Increased FF of STD had carryover effects after weaning, as calves fed STD4 tended $(P=0.10)$ to have higher SG intake than calves fed MOD4 in wk 7 and tended $(P=0.09)$ to also have higher $\mathrm{SG}$ intake in wk 8. A significant effect of MR was observed on SG intake from d 1 to 42 and d 1 to 56. Calves on STD treatments consumed greater amounts $(P<0.05)$ of SG than calves fed MOD diets at weaning and on d 56 (Table 4). Average daily SG intake during the first 56 d was decreased $(P<0.05)$ for calves fed MOD diets compared with STD diets. Feeding frequency did not have an effect on average daily SG intake but an MR $\times$ FF interaction $(P<0.05)$ existed, as calves fed STD4 had greater SG intake than those fed MOD4. Smaller and more frequent MR meals increased SG intake as we had hypothesized; however, this was only true for calves fed STD diets and not MOD diets. Recently published research (Terré et al., 2009; Davis Rincker et al., 2011; Morrison et al., 2012) also demonstrated SG intake reduction with accelerated MR feeding programs. The summation of MR and SG intake (total DMI) from d 1 to 42 and d 1 to 56 was similar among treatments and was not affected by MR or FF (Table 4). By d 56 DMI was similar among all treatments. Factors regulating 
Table 4. Intake of milk replacer (MR), starter grain, and DMI for calves fed either a 20:20 or 26:18 milk replacer (MR) 2 or 4 times daily (n $=12)^{1}$

\begin{tabular}{|c|c|c|c|c|c|c|c|c|}
\hline \multirow[b]{2}{*}{ Item } & \multicolumn{4}{|c|}{ Treatment $^{2}$} & \multirow[b]{2}{*}{$\mathrm{SEM}^{3}$} & \multicolumn{3}{|c|}{ Contrast, ${ }^{4} P$-value } \\
\hline & STD2 & STD4 & MOD2 & MOD4 & & MR & $\mathrm{FF}$ & $\mathrm{MR} \times \mathrm{FF}$ \\
\hline $\mathrm{n}$ & 12 & 12 & 12 & 12 & & & & \\
\hline $\begin{array}{l}\text { Total MR intake, } \mathrm{kg} \\
\text { d } 1 \text { to } 42\end{array}$ & 29.1 & 27.0 & 36.8 & 36.7 & 0.9 & $<0.05$ & 0.37 & 0.41 \\
\hline $\begin{array}{l}\text { Average } \mathrm{MR} \text { intake, } \mathrm{kg} / \mathrm{d} \\
\text { d } 1 \text { to } 42\end{array}$ & 0.70 & 0.64 & 0.88 & 0.87 & $<0.1$ & $<0.05$ & 0.27 & 0.30 \\
\hline $\begin{array}{l}\text { Average starter intake, } \mathrm{kg} / \mathrm{wk} \\
\text { wk } 1 \\
\text { wk } 2 \\
\text { wk } 3 \\
\text { wk } 4 \\
\text { wk } 5 \\
\text { wk } 6 \\
\text { wk } 7 \\
\text { wk } 8\end{array}$ & $\begin{array}{l}0.04 \\
0.20 \\
0.29 \\
0.47 \\
0.62 \\
1.00^{\text {ab }} \\
2.00 \\
2.50\end{array}$ & $\begin{array}{l}0.01 \\
0.14 \\
0.32 \\
0.53 \\
0.73 \\
1.30^{\mathrm{a}} \\
2.40 \\
2.80\end{array}$ & $\begin{array}{l}0.01 \\
0.08 \\
0.20 \\
0.30 \\
0.46 \\
1.00^{\mathrm{ab}} \\
2.00 \\
2.82\end{array}$ & $\begin{array}{l}0.02 \\
0.09 \\
0.12 \\
0.22 \\
0.27 \\
0.76^{\mathrm{b}} \\
1.90 \\
2.52\end{array}$ & $\begin{array}{r}<0.1 \\
<0.1 \\
<0.1 \\
<0.1 \\
<0.1 \\
0.1 \\
0.2 \\
0.2\end{array}$ & $\begin{array}{r}0.37 \\
<0.05 \\
<0.05 \\
<0.05 \\
<0.05 \\
<0.05 \\
0.09 \\
0.96\end{array}$ & $\begin{array}{l}0.31 \\
0.47 \\
0.60 \\
0.89 \\
0.59 \\
0.64 \\
0.55 \\
0.90\end{array}$ & $\begin{array}{r}0.08 \\
0.38 \\
0.24 \\
0.26 \\
0.06 \\
<0.05 \\
0.10 \\
0.09\end{array}$ \\
\hline $\begin{array}{l}\text { Total starter intake, } \mathrm{kg} \\
\text { d } 1 \text { to } 42 \\
\text { d } 1 \text { to } 56\end{array}$ & $\begin{array}{l}18.7 \\
47.4^{\mathrm{ab}}\end{array}$ & $\begin{array}{l}20.9 \\
57.2^{\mathrm{a}}\end{array}$ & $\begin{array}{l}13.3 \\
47.3^{\mathrm{ab}}\end{array}$ & $\begin{array}{l}10.8 \\
38.7^{\mathrm{b}}\end{array}$ & $\begin{array}{l}2.1 \\
4.0\end{array}$ & $\begin{array}{l}<0.05 \\
<0.05\end{array}$ & $\begin{array}{l}0.95 \\
0.87\end{array}$ & $\begin{array}{r}0.24 \\
<0.05\end{array}$ \\
\hline $\begin{array}{l}\text { Average starter intake, } \mathrm{kg} / \mathrm{wk} \\
\text { d } 1 \text { to } 56\end{array}$ & $0.90^{\mathrm{ab}}$ & $1.0^{\mathrm{a}}$ & $0.89^{\mathrm{ab}}$ & $0.73^{\mathrm{b}}$ & 0.1 & $<0.05$ & 0.99 & $<0.05$ \\
\hline $\begin{array}{l}\text { Total DMI, kg } \\
\text { d } 1 \text { to } 42 \\
\text { d } 1 \text { to } 56\end{array}$ & $\begin{array}{l}47.6 \\
78.6\end{array}$ & $\begin{array}{l}47.5 \\
84.4\end{array}$ & $\begin{array}{l}49.4 \\
84.2\end{array}$ & $\begin{array}{l}47.0 \\
78.3\end{array}$ & $\begin{array}{l}2.5 \\
4.2\end{array}$ & $\begin{array}{l}0.79 \\
0.95\end{array}$ & $\begin{array}{l}0.62 \\
0.98\end{array}$ & $\begin{array}{l}0.65 \\
0.18\end{array}$ \\
\hline
\end{tabular}

$\overline{\mathrm{a}, \mathrm{b}}$ Within a row, means with different superscripts differ $(P<0.05)$.

${ }^{1}$ The $20: 20 \mathrm{MR}$ contained $20 \% \mathrm{CP}$ and $20 \%$ fat; the $26: 18 \mathrm{MR}$ contained $26 \% \mathrm{CP}$ and $18 \%$ fat.

${ }^{2}$ STD2 $=$ conventional MR (20\% CP and $20 \%$ fat) fed twice daily at $1.5 \%$ of BW; STD $4=$ conventional MR (20\% CP and $20 \%$ fat) fed 4 times daily at $1.5 \%$ of BW; MOD2 = modified MR $(26 \% \mathrm{CP}$ and $18 \%$ fat $)$ fed twice daily at $2.0 \%$ of BW; MOD $4=$ modified MR $(26 \% \mathrm{CP}$ and $18 \%$ fat) fed 4 times daily at $2.0 \%$ of BW. Calves on all treatments were weaned at $42 \mathrm{~d}$. An $18 \%$ CP starter and water were offered free choice. ${ }^{3}$ Largest SEM for treatment effects.

${ }^{4} \mathrm{MR}=20: 20 \mathrm{MR}$ versus 26:18 $\mathrm{MR} ; \mathrm{FF}=$ feeding frequency (2 vs. 4 times/d); $\mathrm{MR} \times \mathrm{FF}=$ interaction between $\mathrm{MR}$ and $\mathrm{FF}$.

Table 5. Calculated intake of $\mathrm{CP}$ and fat from milk replacer (MR), starter grain, and total intake (MR intake + starter intake) from d 1 to 42 and d 1 to 56 for calves fed a 20:20 MR twice or 4 times daily and calves fed a 26:18 MR either twice or 4 times daily $(\mathrm{n}=12$ )

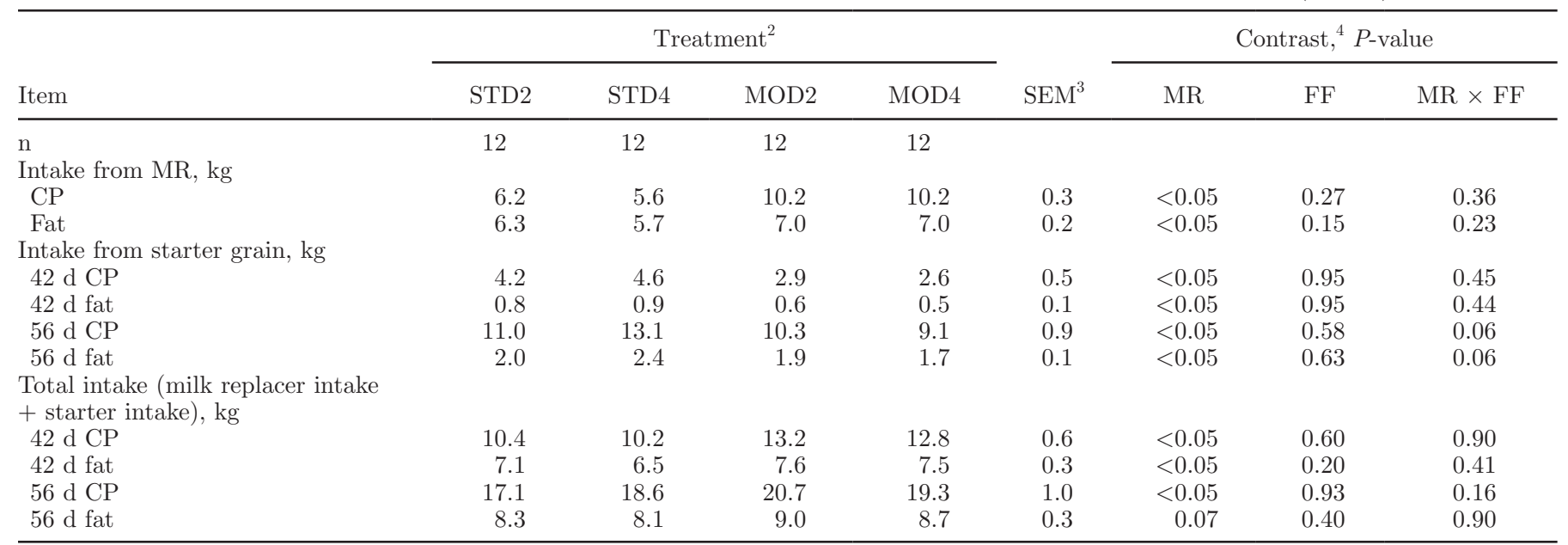

${ }^{1}$ The 20:20 MR contained 20\% CP and 20\% fat; the $26: 18 \mathrm{MR}$ contained $26 \% \mathrm{CP}$ and $18 \%$ fat.

${ }^{2}$ STD2 $=$ conventional MR (20\% CP and $20 \%$ fat) fed twice daily at $1.5 \%$ of BW; STD $4=$ conventional MR (20\% CP and $20 \%$ fat) fed 4 times daily at $1.5 \%$ of BW; MOD2 = modified MR (26\% CP and $18 \%$ fat) fed twice daily at $2.0 \%$ of BW; MOD $4=$ modified MR (26\% CP and $18 \%$ fat) fed 4 times daily at $2.0 \%$ of BW. Calves on all treatments were weaned at $42 \mathrm{~d}$. An $18 \% \mathrm{CP}$ starter and water were offered free choice. ${ }^{3}$ Largest SEM for treatment effects.

${ }^{4} \mathrm{MR}=20: 20 \mathrm{MR}$ versus 26:18 MR; FF = feeding frequency (2 vs. 4 times/d); MR $\times \mathrm{FF}=$ interaction between $\mathrm{MR}$ and $\mathrm{FF}$. 
Table 6. Concentration of plasma NEFA and total lipids in biopsies of skeletal muscle of calves fed a 20:20 milk replacer (MR) twice or 4 times daily and calves fed a $26: 18$ MR either twice or 4 times daily $(\mathrm{n}=12)^{1}$

\begin{tabular}{|c|c|c|c|c|c|c|c|c|c|}
\hline \multirow[b]{2}{*}{ Item } & \multicolumn{4}{|c|}{ Treatment $^{2}$} & \multirow[b]{2}{*}{$\mathrm{SEM}^{3}$} & \multicolumn{4}{|c|}{ Contrast, ${ }^{4} P$-value } \\
\hline & STD2 & STD4 & MOD2 & MOD4 & & MR & $\mathrm{FF}$ & $\mathrm{MR} \times \mathrm{FF}$ & Day \\
\hline Average NEFA, mM & 0.18 & 0.19 & 0.21 & 0.28 & 0.02 & $<0.05$ & 0.06 & 0.18 & $<0.05$ \\
\hline d 14 & 0.21 & 0.25 & 0.22 & 0.31 & 0.03 & & & & \\
\hline d 21 & 0.18 & 0.26 & 0.29 & 0.31 & 0.03 & & & & \\
\hline d 28 & 0.17 & 0.18 & 0.19 & 0.33 & 0.04 & & & & \\
\hline Average muscle total lipid, $\%$ wet weight & $1.3^{\mathrm{a}}$ & $1.3^{\mathrm{a}}$ & $1.9^{\mathrm{b}}$ & $1.7^{\mathrm{b}}$ & 0.18 & $<0.05$ & 0.71 & 0.61 & 0.54 \\
\hline d 21 & 1.4 & 1.2 & 1.9 & 1.8 & 0.24 & & & & \\
\hline d 42 & 1.3 & 1.3 & 1.8 & 1.5 & 0.20 & & & & \\
\hline
\end{tabular}

$\overline{\mathrm{a}, \mathrm{b}}$ Within a row, means with different superscripts differ $(P<0.05)$.

${ }^{1}$ The $20: 20 \mathrm{MR}$ contained $20 \% \mathrm{CP}$ and $20 \%$ fat; the $26: 18 \mathrm{MR}$ contained $26 \% \mathrm{CP}$ and $18 \%$ fat.

${ }^{2}$ STD $2=$ conventional MR (20\% CP and $20 \%$ fat) fed twice daily at $1.5 \%$ of BW; STD $4=$ conventional MR (20\% CP and $20 \%$ fat) fed 4 times daily at $1.5 \%$ of BW; MOD2 = modified MR $(26 \% \mathrm{CP}$ and $18 \%$ fat) fed twice daily at $2.0 \%$ of BW; MOD $4=$ modified MR $(26 \% \mathrm{CP}$ and $18 \%$ fat) fed 4 times daily at $2.0 \%$ of BW. Calves on all treatments were weaned at $42 \mathrm{~d}$. An $18 \% \mathrm{CP}$ starter and water were offered free choice.

${ }^{3} \mathrm{SEM}=$ largest SEM for treatment effects.

${ }^{4} \mathrm{MR}=20: 20 \mathrm{MR}$ versus 26:18 MR; FF = feeding frequency (2 vs. 4 times/d); $\mathrm{MR} \times \mathrm{FF}=$ interaction between $\mathrm{MR}$ and $\mathrm{FF}$.

SG intake and feeding behavior should be evaluated to help understand the interaction of the amount and composition of nutrients from MR on SG intake.

Altering the amount and frequency of milk or MR may affect calf behavior. Thomas et al. (2001) demonstrated that calves fed restricted quantities of milk vocalized more than calves fed milk ad libitum. Calves fed restricted quantities of milk were also more active and more competitive than calves fed milk ad libitum (De Paula Vieira et al., 2008). Bøe and Havrevoll (1993) reported calves with access to $0.5 \mathrm{~L}$ of milk every $2 \mathrm{~h}$ consumed the maximum of 12 allotted meals per day. In addition to the visits where they consumed milk, they visited the feeder up to 30 times per day where they did not receive milk because less than $2 \mathrm{~h}$ had elapsed since the last meal.

\section{Protein and Fat Intake}

The calculated intakes of $\mathrm{CP}$ and fat from MR and SG are described in Table 5. As planned, the intakes of $\mathrm{CP}$ and fat were higher $(P<0.05)$ for MOD calves than for STD calves. Due to higher SG intake, intake of CP and fat from SG was higher $(P<0.05)$ for STD calves through d 42 and 56. Calculated total intake $(\mathrm{MR}+\mathrm{SG})$ of $\mathrm{CP}$, however, through d 42 and d 56 were higher $(P<0.05)$ for MOD calves. Calculated total intake (MR $+\mathrm{SG})$ of fat, however, through d 42 was higher $(P<0.05)$ and tended $(P=0.07)$ to be higher for MOD compared with STD. Feeding frequency did not alter total $\mathrm{CP}$ or fat intake through the first 42 or $56 \mathrm{~d}$ of nursery calf feeding.

\section{Plasma NEFA and Muscle Total Lipids}

Plasma NEFA concentrations are reported in Table 6. Plasma NEFA concentrations were affected by MR and decreased $(P<0.05)$ with calf age. Calves fed MOD diets had higher $(P<0.05)$ serum NEFA concentrations than calves fed STD diets. Additionally, MOD4 had the highest serum NEFA concentration, resulting in a tendency $(P=0.06)$ for an effect of FF. Serum

Table 7. Spearman correlations among weekly measures of calf age, serum NEFA, mean ambient temperature, and starter intake ${ }^{1}$

\begin{tabular}{lccc}
\hline Variable & $\begin{array}{c}\text { Calf age, } \\
\text { wk }\end{array}$ & $\begin{array}{c}\text { Serum } \\
\text { NEFA }\end{array}$ & $\begin{array}{c}\text { Mean weekly } \\
\text { ambient temperature }\end{array}$ \\
\hline Serum NEFA & -0.26 & & \\
& $<0.05$ & & \\
Mean weekly ambient temperature & -0.04 & 0.05 & \\
Starter intake & 0.49 & 0.45 & -0.08 \\
& 0.70 & -0.31 & 0.19 \\
\hline
\end{tabular}

${ }^{1}$ Correlation coefficient (r) is top number, with the corresponding $P$-value beneath. 
Table 8. Least squares means for fecal scores of calves fed either a 20:20 or 26:18 milk replacer (MR) 2 or 4 times daily $^{1}$

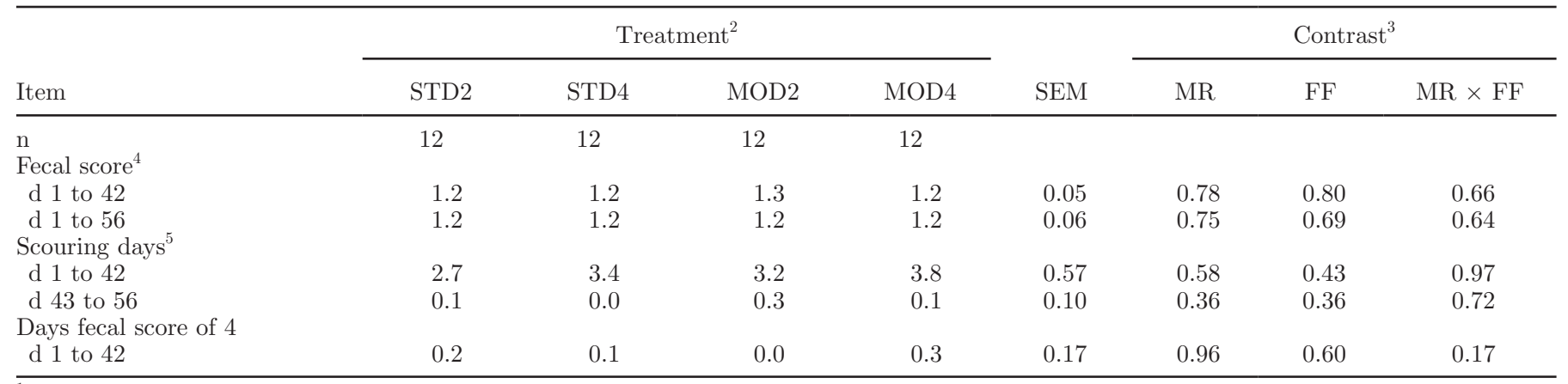

${ }^{1}$ The $20: 20 \mathrm{MR}$ contained $20 \% \mathrm{CP}$ and $20 \%$ fat; the $26: 18 \mathrm{MR}$ contained $26 \% \mathrm{CP}$ and $18 \%$ fat.

${ }^{2} \mathrm{STD} 2=$ conventional MR (20\% CP and $20 \%$ fat) fed twice daily at $1.5 \%$ of BW; STD4 = conventional MR (20\% CP and $20 \%$ fat) fed 4 times daily at $1.5 \%$ of BW: MOD2 = modified MR $(26 \% \mathrm{CP}$ and $18 \%$ fat $)$ fed twice daily at $2.0 \%$ of BW: MOD $4=$ modified MR $(26 \% \mathrm{CP}$ and $18 \%$ fat) fed 4 times daily at 2.0\% of BW. Calves on all treatments were weaned at $42 \mathrm{~d}$. An $18 \% \mathrm{CP}$ starter and water were offered free choice.

${ }^{3} \mathrm{MR}=20: 20 \mathrm{MR}$ versus 26:18 $\mathrm{MR} ; \mathrm{FF}=$ feeding frequency (2 vs. 4 times/d); $\mathrm{MR} \times \mathrm{FF}=$ interaction between $\mathrm{MR}$ and $\mathrm{FF}$.

${ }^{4}$ Fecal score system: $1=$ normal; $2=$ semi-formed, pasty; 3 = loose, but stays on top of bedding; $4=$ watery, shifts through bedding. Abnormal fecal scores were days with scores $\geq 3$.

${ }^{5}$ Scouring day $=$ any day with a fecal score $\geq 3$.

NEFA in MOD4 calves peaked on d 28 and decreased thereafter. On the contrary, Stanley et al. (2002) reported that calf plasma NEFA concentrations were not affected by MR FF (once daily versus twice daily feeding). The source of NEFA is of both dietary origin and also possibly from mobilization of adipose tissue (Zhang et al., 2010; Nonnecke et al., 2009). Increased concentrations of NEFA indicate adipose mobilization in support of energy demands before the morning feeding. Higher total fat intake for MOD fed calves likely contributed to increased plasma NEFA; however, an effect of thermal stress may have occurred as well due to the cold weather during the trial. The MR used in this study contained $18 \%$ fat (DM basis) for MOD diets, which when fed at $2.0 \%$ of BW resulted in higher fat intake by calves on these treatments than calves fed MR containing $20 \%$ fat at $1.5 \%$ of BW. Early in the nursing phase, calves are dependent on glucose and FA supplied in MR as their main dietary energy sources (Chilliard, 1993). Calves rely more heavily on organic acids from fermentation from SG as their primary energy source during the initiation of weaning from d 35 to 42, during which time NEFA concentrations decline.

Calves fed MOD diets had greater $(P<0.05)$ muscle total lipid concentration in biopsies of semitendinosus muscle than calves fed STD diets (Table 6). Muscle total lipid concentration was unaffected by $\mathrm{FF}$ and concentrations were similar at both 21 and $42 \mathrm{~d}$. Averages of muscle total lipids were below $2 \%$. Total lipids measured in muscle biopsies have been used to explore treatment effects on amounts of lipid in muscle during the transition period in adult dairy cattle (Dann et al., 2006). Muscle total lipids in calves in this study were about half that reported in adult dairy cattle (Dann et al., 2006). Increased amounts of total lipid in muscle have previously been used as an indicator of metabolic status (Kelley, 2002). We anticipated greater muscle lipid accumulation in nursery calves fed MOD compared with STD diets. To our knowledge, this is the first study to report measures of total lipid content in muscle biopsies in nursery calves fed varying amounts of nutrients from MR. Future research should correlate the composition of muscle biopsy measurements with that of whole body composition to aid in interpretation of muscle biopsy composition data.

The thermoneutral zone of the young calf ranges from 15 to $25^{\circ} \mathrm{C}$ and varies with calf age, weight, environmental temperature, and other stressors (Schrama et al., 1993). In a thermoneutral environment, the calf is not required to elicit specific heat-conserving or heat-dissipating mechanisms to maintain core body temperature (NRC, 2001). When the lower critical temperature, defined as the effective ambient temperature dependent on wind velocity, humidity, and tissue insulation is reached, a calf must produce more heat to maintain body temperature (Nonnecke et al., 2009).

Calves fed MOD4 had higher NEFA and lower SG intake. Spearman correlations among weekly measures of calf age, plasma NEFA, ambient temperature and SG intake were calculated (Table 7). As expected, NEFA was negatively correlated $(P<0.05)$ with SG intake and calf age. Starter intake was not significantly correlated with weekly ambient temperature and is likely due to the relatively consistently cold weather $(-6$ and $-14^{\circ} \mathrm{C}$ in January to a high of $19^{\circ} \mathrm{C}$ and a low of $7^{\circ} \mathrm{C}$ in April) during this study. 


\section{Health and Fecal Measurements}

In this experiment, $\mathrm{MR}$ and $\mathrm{FF}$ did not affect fecal score from d 1 to 42 or d 1 to 56 (Table 8). Through 56 $\mathrm{d}$, fecal scores and days scouring (fecal scores $\geq 3$ ) were not affected by MR or FF.

\section{CONCLUSIONS}

Calves fed the modified accelerated program had greater $\mathrm{CP}$ and fat intake, resulting in increased ADG, greater G:F ratios, greater heart girth, greater circulating NEFA and muscle total lipid, and lower SI compared with the standard MR program. Accelerated fed calves consumed less SG but total DMI was not different from the standard MR program. Increased FF had no effect on growth, SI, or G:F ratio. Increased FF for STD treatments resulted in greater SG intake at weaning but increased $\mathrm{FF}$ of the MOD diet did not have this effect. Meal volume and caloric density are likely important factors for consideration when increasing the $\mathrm{FF}$ and meal size fed to nursery calves.

\section{ACKNOWLEDGMENTS}

The authors thank the staff at the University of Minnesota (St. Paul) Dairy Research and Teaching Unity for animal care and Milk Products Inc. (Chilton, WI) for partial milk replacer donation.

\section{REFERENCES}

Albright, L. L., and C. W. Arave. 1997. The Behaviour of Cattle. CAB International, Wallingford, UK.

AOAC (Association of Official Analytical Chemists). 1990. Official Methods of Analysis. 15th ed. AOAC, Arlington, VA.

AOAC International. 2000. Official Methods of Analysis. 3rd ed. AOAC International, Arlington, VA.

Bach, A., N. Valls, A. Solans, and T. Torrent. 2008. Associations between nondietary factors and dairy herd performance. J. Dairy Sci. 91:3259-3267.

Bartlett, K. S., K. McKeith, M. J. VandeHaar, G. E. Dahl, and J. K. Drackley. 2006. Growth and body composition of diary calves fed milk replacers containing different amount of protein at two feeding rates. J. Anim. Sci. 84:1454-1467.

Blome, R. M., J. K. Drackley, F. K. McKeith, M. F. Hutjens, and G. C. McCoy. 2003. Growth, nutrient utilization, and body composition of dairy calves fed milk replacers containing different amounts of protein. J. Anim. Sci. 81:1641-1655.

Bøe, K., and Ø. Havrevoll. 1993. Cold housing and computer controlled milk feeding for dairy calves. Behavior and performance. Anim. Prod. 57:183-191.

Borderas, T. F., A. M. B. Passillé, and J. Rushen. 2009. Feeding behavior of calves fed small or large amounts of milk. J. Dairy Sci. 92:2843-2852.

Brown, E. G., M. J. Vandehaar, K. M. Daniels, J. S. Liesman, L. T. Chapin, D. H. Keisler, and M. S. Weber Nielsen. 2005. Effects of increasing energy and protein intake on body growth and carcass composition of heifer calves. J. Dairy Sci. 88:585-594.

Chilliard, Y. 1993. Dietary fat and adipose tissue metabolism in ruminants, pigs, and rodents: A review. J. Dairy Sci. 76:3897-3931.
Cowles, K. E., R. A. White, N. L. Whitehouse, and P. S. Erickson. 2006. Growth characteristics of calves fed an intensified milk replacer regimen with additional lactoferrin. J. Dairy Sci. 89:48354845.

Dann, H. M., N. B. Litherland, J. P. Underwood, M. Bionaz, A. D'Angelo, J. W. McFadden, and J. K. Drackley. 2006. Diets during far-off and close-up dry periods affect periparturient metabolism and lactation in multiparous cows. J. Dairy Sci. 89:3563-3577.

Davis, C. L., and J. K. Drackley. 1998. The Development, Nutrition, and Management of the Young Calf. Iowa State University Press, Ames.

Davis Rincker, L. E., M. J. VandeHaar, C. A. Wolf, J. S. Liesman, L. T. Chapin, and M. S. Weber Nielsen. 2011. Effect of intensified feeding of heifer calves on growth, pubertal age, calving age, milk yield and economics. J. Dairy Sci. 94:3554-3567.

De Paula Vieira, A., V. Guesdon, A. M. de Passillé, M. A. G. von Keyserlingk, and D. M. Weary. 2008. Behavioral indicators of hunger in dairy calves. Appl. Anim. Behav. Sci. 109:180-189.

Diaz, M. C., M. E. Van Amburgh, J. M. Smith, J. M. Kelsey, and E. L. Hutten. 2001. Composition of growth of Holstein calves fed milk replacer from birth to 105-kilogram body weight. J. Dairy Sci. 84:830-842.

Donnelly, P. E., and J. B. Hutton. 1976. Effects of dietary protein and energy on the growth of Friesian bull calves. II. Effects of level of feed intake and dietary protein content on body composition. $\mathrm{N}$. Z. J. Agric. Res. 19:289-297.

Flower, F. C., and D. M. Weary. 2001. Effects of early separation on the dairy cow and calf: 2 . Separation at 1 day and 2 weeks after birth. Appl. Anim. Behav. Sci. 70:275-284.

Gerrits, W. J. J., G. H. Tolman, J. W. Schrama, S. Tamminga, M. W. Bosch, and M. W. A. Verstegen. 1996. Effect of protein and protein-free energy intake on protein and fat deposition rates in preruminant calves of 80 to $240 \mathrm{~kg}$ live weight. J. Anim. Sci. $74: 2129-2139$.

Hara, A., and N. S. Radin. 1978. Lipid extraction of tissues with a low-toxicity solvent. Anal. Biochem. 90:420-426.

Hill, S. R., K. F. Knowlton, K. M. Daniels, R. E. James, R. E. Pearson, and A. V. Capuco. 2008. Effects of milk replacer composition on growth, body composition, and nutrient excretion in preweaned Holstein heifers. J. Dairy Sci. 91:3145-3155.

Huber, J. T., A. G. Silva, O. F. Campos, and C. M. Mathieu. 1984. Influence of feeding different amounts of milk on performance, health, and absorption capability of baby calves. J. Dairy Sci. 67:2957-2963.

Jasper, J., and D. M. Weary. 2002. Effects of ad libitum milk intake on dairy calves. J. Dairy Sci. 85:3054-3058.

Jenny, B. F., H. J. Van Dijk, and L. W. Grimes. 1982. Performance of calves fed milk replacer once daily at various fluid intakes and dry matter concentrations. J. Dairy Sci. 65:2345-2350.

Kelley, D. E. 2002. Skeletal muscle triglycerides. An aspect of regional adiposity and insulin resistance. Ann. N. Y. Acad. Sci. 967:135145.

Kertz, A. F., L. R. Prewitt, and J. P. Everett Jr. 1979. An early weaning calf program: Summarization and review. J. Dairy Sci. 62:1835-1843.

Khan, M. A., H. J. Lee, W. S. Lee, H. S. Kim, S. B. Kim, K. S. Ki, J. K. Ha, H. G. Lee, and Y. J. Choi. 2007. Pre- and postweaning performance of Holstein female calves fed milk through step-down and conventional methods. J. Dairy Sci. 90:876-885.

Morrison, S. J., H. C. Wicks, A. F. Carson, R. J. Fallon, J. Twigge, D. J. Kilpatrick, and S. Watson. 2012. The effect of calf nutrition on the performance of dairy herd replacements. Animal 6:909-919.

Nonnecke, B. J., M. R. Foote, B. L. Miller, M. Fowler, T. E. Johnson, and R. L. Horst. 2009. Effects of chronic environmental cold on growth, health, and selected metabolic and immunologic responses of preruminant calves. J. Dairy Sci. 92:6134-6143.

NRC. 2001. Nutrient Requirements of Dairy Cattle. 7th rev. ed. National Academy Press. Washington, DC.

Quigley, J. D., T. A. Wolfe, and T. H. Elsasser. 2006. Effects of additional milk replacer feeding on calf health, growth, and selected blood metabolites in calves. J. Dairy Sci. 89:207-216. 
Raeth-Knight, M., H. Chester-Jones, S. Hayes, J. Linn, R. Larson, D. Ziegler, B. Ziegler, and N. Broadwater. 2009. Impact of conventional or intensive milk replacer programs on Holstein heifer performance through six months of age and during first lactation. J. Dairy Sci. 92:799-809.

SAS Institute. 2001. SAS User's Guide: Statistics. Version 9.2 ed. SAS Inst. Inc., Cary, NC.

Schingoethe, D. J., D. P. Casper, J. K. Drackley, and F. C. Ludens. 1986. Increased solids intake and feeding frequency for calves in hutches during cold weather. J. Dairy Sci. 69:1063-1069.

Schrama, J. W., A. Arieli, H. A. Brandsma, P. Luiting, and M. W. A. Verstegen. 1993. Thermal requirements of young calves during standing and lying. J. Anim. Sci. 71:3285-3292.

Stanley, C. C., C. C. Williams, B. F. Jenny, J. M. Fernandez, H. G. Bateman II, W. A. Nipper, J. C. Lovejoy, D. T. Gantt, and G. E.
Goodier. 2002. Effects of feeding milk replacer once versus twice daily on glucose metabolism in Holstein and Jersey calves. J. Dairy Sci. 85:2335-2343.

Terré, M., C. Tejero, and A. Bach. 2009. Long-term effects on heifer performance of an enhanced-growth feeding program applied during the preweaning period. J. Dairy Res. 76:331-339.

Thomas, T. J., D. M. Weary, and M. C. Appleby. 2001. Newborn and 5 -week-old calves vocalize in response to milk deprivation. Appl. Anim. Behav. Sci. 74:165-173.

von Keyserlingk, M. A. G., and D. M. Weary. 2007. Maternal behavior in cattle: A review. Horm. Behav. 52:106-113.

Zhang, Y. Q., D. C. He, and Q. X. Meng. 2010. Effect of a mixture of steam-flaked corn and soybeans on health, growth, and selected blood metabolism of Holstein calves. J. Dairy Sci. 93:2271-2279. 